\title{
Business as usual in Indonesia: governance factors effecting the acceleration of the deforestation rate after the introduction of REDD+
}

\author{
Ashley Enrici $^{1} \cdot$ Klaus Hubacek $^{1}$ \\ ${ }^{1}$ Department of Geographical Sciences, University of Maryland, 2181 LeFrak Hall, College Park, MD 20740, USA
}

Received: 7 January 2016/Revised: 6 June 2016/Accepted: 21 June 2016/Published online: 2 July 2016

(c) Joint Center on Global Change and Earth System Science of the University of Maryland and Beijing Normal University and Springer-Verlag Berlin Heidelberg 2016

\begin{abstract}
Indonesia has the third largest extent of tropical forest in the world and has been extensively involved in Reducing Emissions from Deforestation and forest Degradation (REDD+). Despite significant commitments from the Government of Indonesia (GOI) and the international community, the deforestation rate in Indonesia has not stabilized or decreased in the initial years after REDD+'s introduction in 2007, and as of 2012 was arguably the highest in the world. Globally, it is essential to understand how REDD+ is going to affect the deforestation rate as it is implemented in many countries. In order to constructively evaluate these continued increases in rates of deforestation in Indonesia, this article will explore some of the challenges of forest governance in Indonesia as identified by stakeholders of REDD+ and as described in the policy documents and other literature. Despite a number of changes in laws and regulations that came about as a result of REDD+ in Indonesia, weak institutional capacity and corruption have resulted in a situation that might be described as essentially, business as usual. Furthermore, new policies that have resulted from the introduction of REDD+ designed to help forest governance, such as the presidential moratorium on new licenses for forest use, may in fact have motivated some parties to initially act in ways that have contributed to the increase in deforestation-particularly through leakage from institutionally recognized forests to non-institutionally recognized forest areas. Problematic governance and corruption continue to pose problems that haunt the forestry sector and allow encroachment onto protected areas.
\end{abstract}

Ashley Enrici

Enriciam@umd.edu
Keywords REDD+ - Indonesia - Forest governance . Deforestation · Forest policy

\section{Introduction}

Between 2000 and 2012, 2.3 million $\mathrm{km}^{2}$ of global forest cover was lost (Hansen et al. 2013). Deforestation is the second largest source of anthropogenic carbon emissions (Van der Werf et al. 2009) and is a major contributor to climate change (IPCC 2014). Forests provide invaluable ecosystem services, are hotspots of biodiversity, and a direct source of livelihood for 65 million people in Indonesia alone (Barber et al. 2002). The most recent data for Indonesia show that the 2013 percent of total tree cover loss outside of plantations was $47.13 \%$ (537,294 ha), and in 2014 it was $62.31 \%$ (928,765 ha) (WRI GFW 2016). As one of the most biodiverse places on the planet, and with a deforestation rate that has been accelerating in recent years (Margono et al. 2014), forest governance reform is urgently needed in Indonesia.

However, due to the complex political, economic, and social systems that exist there implementation of policies and programs to improve forest management has proven to be highly challenging (Santosa et al. 2013). Indonesia is an emerging market with a growing economy. The activities that fuel this economic growth, such as palm oil plantations, mining, and timber extraction, are many of the same activities that result in deforestation and contribute to Indonesia's carbon emissions. While much of Indonesia's forest cover has already been lost, much more is in danger of conversion-approximately $34.6 \%$ ( $\sim 26.8 \mathrm{Mha})$ of the remaining forest cover is currently located within industrial concessions (Abood et al. 2014). 
Reducing Emissions from Deforestation and Forest Degradation (REDD) is a global initiative developed by the United Nations for protecting forests and reducing carbon emissions. The initial concept behind REDD is to offer developing countries incentives to reduce activities that lead to deforestation, therefore maintaining the enormous amounts of carbon sequestered by forests (UN FAO 2015) while still maintaining economic growth (UN REDD Programme 2015). REDD+ also aims to include other important benefits beyond carbon sequestration, such as biodiversity preservation and community forest rights, which are increasingly being recognized as essential for successful forest management (Stevens et al. 2014). And while initially the plan for REDD+ offered much hope, the challenges associated with its implementation have raised many questions. The beginnings of REDD+ implementation have already lead to doubts about its potential to achieve what it is meant to and stakeholder fatigue in many instances. Of central concern is what effect REDD+, and related activities, will have on deforestation rates in both the immediate and long-term future as policies created to support REDD+ may have unintended effects on the ground. This is one of the most central questions to REDD+, which this article begins to address by exploring how forest governance in Indonesia may have contributed to rising deforestation rates since the introduction of REDD+.

Regardless of the doubts and challenges, there have arguably been some benefits resulting from REDD+since its introduction in Indonesia in 2008, the discourse about improving forest governance has at least initially increased (Cronin and Santoso 2010), demonstration activities have been implemented, and Indonesia's government has made reforms to forest policy (Agung et al. 2014). Yet, despite significant commitments from both the Government of Indonesia (GOI) and the international community, toward REDD+ and the reduction in deforestation-related emissions (Government of Norway and Government of Indonesia 2010), the deforestation rate in Indonesia has accelerated over the period from 2008 to 2012 (Hansen et al. 2013; Margono et al. 2014). The results of the Hansen et al. (2013) publication have been controversial as they included commercial forestry dynamics; however, the subsequent publication by Margono et al. 2014 addressed these concerns by excluding commercial forestry dynamics and clearly defining "primary forest" within the boundaries of that study. While the long-term impact of REDD + remains to be seen, it is known that in the initial years after the introduction of REDD+ the deforestation rate in Indonesia continued to increase and identifying what is behind this increase can help to guide future efforts toward REDD+.

\subsection{Background: deforestation and forest governance in Indonesia}

Successful forest management in Indonesia faces many challenges, including corruption, overlapping authority, and weak management practices (Center for Forestry Planning and Statistics and MoF 2009). As they are used here, the term government shall refer to the actual officials and agencies appointed to the Indonesian government, while governance shall refer to the overarching policy and outcomes that come as a result of the actions of the Indonesian government. Many of the governance issues can be traced back to the Suharto Regime, the period when Suharto was President of Indonesia lasting from 1966 to 1998 and the subsequent decentralization. Throughout this period, there was a highly centralized governance system with strict, often violent, enforcement (Anderson 2001). Control of forests was often taken from indigenous forest communities and handed over to military powers or corporate interests (McCarthy 2000). Before Suharto gained power, the tropical forests on Indonesia's outer islands remained largely intact, but after his presidency began in 1966 it is estimated that over 40 million hectares was lost (Barr 2001). After the Suharto regime, rough data from 2001 to 2014 indicate that approximately $11.4 \%$ ( $\sim 18.5 \mathrm{MHa})$ of remaining forests were lost during that time (WRI GFW 2016) And after the end of the Suharto regime, Indonesia's government rapidly transitioned into a decentralized system and much of the authority over land use fell to regional authorities (McCarthy 2004). The transition away from a strong central government led to a disconnect between the national government and regional governments, which allowed corruption to flourish at the district level and compounded the corrupt system already in place during the Suharto regime (Smith et al. 2003). Today, corruption is still a major problem for forest management in Indonesia [Dermawan et al. 2011; Human Rights Watch (HRW) 2013] and many residual land tenure issues from the Suharto regime remain (Neef et al. 2007). Furthermore, there is an overlap of national and regional authority in many regions, which combined with corruption and lack of institutional capacity leads to weak governance of forest areas (Brockhaus et al. 2012). Even successful management of conservation forests can be problematic despite the fact that these areas are officially designated as protected forests or National Parks (Yuliani et al. 2010). These issues combined with Indonesia's rapidly expanding economy manifest in creating a pathway for high deforestation rates.

While an expanding population, growing economy, and weak governance are the indirect drivers of deforestation in Indonesia, expanding industries is the direct causes of 
deforestation-namely, palm oil, mining, and timber (Kissinger et al. 2012). Forest fires, often set illegally and exacerbated by weak institutional capacity, are another major cause of deforestation in Indonesia (Tacconi 2003). Over 100,000 fires were recorded for the year 2015 and resulted in Indonesia emitting more carbon from fires alone than the entire USA economy (Harris et al. 2015a) and moving Indonesia from the world's sixth largest emitter of carbon to the fourth in just 6 weeks (Harris et al. 2015b). While these fires were made worse by conditions caused by an El Nino Southern Oscillation event, there are policies and aspects of governance which hamper the response to such fires (Tacconi 2003). Furthermore, they are sometimes intentionally and illegally set and precede the use of land for other interests such as logging or agriculture (Applegate et al. 2001; Fitzherbert et al. 2008). Once a forest has been degraded by fire, or other uses, it is no longer considered primary forest and more easily approved for conversion to palm oil or mining.

Palm oil is an integral part of Indonesia's expanding economy, and the government's support of palm oil interests has the potential to conflict with other goals set for the reduction in deforestation (McFarland et al. 2015; Simamora 2011). In the period from 1990 to 2010, the palm oil area in Indonesia increased by over $600 \%$ to a total of about 7.8 million hectares and during this time over $90 \%$ of deforestation from palm oil occurred in Sumatra and Kalimantan (Hansen et al. 2009), regions known for their high levels of biodiversity (Barber et al. 2002). From 2000 to 2010, palm oil on Kalimantan alone expanded by $278 \%$, and $90 \%$ of palm oil expansion on the island from 1990 to 2010 occurred on forested land (Carlson et al. 2013). Sumatra and Kalimantan are also the two islands of Indonesia with the highest rates of forest loss, Sumatra lost $17.6 \%$ and Kalimantan lost $7.9 \%$ of their overall forest cover from 2000 to 2012 (Margono et al. 2014). Legal and illegal logging are also problematic and global demand, and high prices for timber have encouraged the government to formulate policies allowing for intensive timber harvesting (Kissinger et al. 2012). Much of the mining in Indonesia occurs in heavily forested regions, and these operations are frequently established illegally in conservation areas or protection forest (Contreras-Hermosilla et al. 2005; Indrarto et al. 2012). While much of Indonesia's forest cover has been lost to these drivers of deforestation, much more is in danger of conversion-as of 2010, in Kalimantan alone, approximately $79 \%$ of the palm oil licenses covering $90 \%$ of the remaining forest on the island have not yet been activated (Carlson et al. 2013).

The recent acceleration of deforestation rates in Indonesia has happened in spite of a number of activities and commitments by the Government of Indonesia toward reducing deforestation. In 2009, the President of Indonesia,
Susilo Bambang Yudhoyono, pledged to reduce emissions by $26 \%$ without help from other countries, and $41 \%$ with outside help, by the year 2020. On May 26, 2010, Indonesia's Government signed a Letter of Intent with the Government of Norway to implement REDD + and meet certain deforestation reduction goals, with the promise of $\$ 1$ billion USD for the successful achievement of those goals. This agreement stated that Indonesia would develop a national REDD+ strategy, establish a REDD+ agency, and institute a moratorium on the sale of licenses for natural forest and peatland. And following the Letter of Intent in May 2011, President Yudhoyono declared the moratorium officially (Pres. Instruction 10/2011; Pres. Instruction 6/2013). In addition, there has been increased discourse about, and reforms to, forest governance-increased recognition of customary official forest (Natahadibrata 2013); designation of forest management units (FMU) (Djajono and Siswanty 2011); and efforts toward increased attention to transparency through the One Map program, which aims to create one source of information for all land use and land use licensing for all of Indonesia, something that does not currently exist (UKP4 2012). And in 2015, the new President, Joko Widodo, made an agreement with the Prime Minister of Norway to continue the efforts set forth by the initial letter of intent (Parlina 2015). The following sections address some of the reasons why the deforestation rate in Indonesia has continued to accelerate during the initial period of REDD+'s introduction (Hansen et al. 2013; Margono et al. 2014) despite these actions.

\subsection{Methods}

This paper aims to identify a number of factors that contribute to the complexity of the overall forest management situation in Indonesia, and which may hinder efforts toward reducing the deforestation rate as brought forth by stakeholders of REDD+ and supported by the relevant literature. The basis and foundation for this paper are derived from over 18 months of fieldwork in Indonesia working with stakeholders of REDD+. The fieldwork included participant observation at dozens of meetings and 68 interviews at various scales of governance-international, national, provincial, district, and local. Interviews were semi-structured and were recorded and later transcribed by the lead author. Informants were chosen based on their involvement in REDD+ from various sectors including: government, civil service, non-governmental organizations (NGOs), multilateral development banks, research, private entities, and forest communities. The aspects of governance discussed here were repeatedly mentioned during the fieldwork in meetings or interviews and thus emerged as major aspects of governance that contributed to the challenges of implementing REDD+ and forest governance in 
Indonesia. These inputs are then further built upon with literature that exemplifies how these issues correlate with challenges to reducing deforestation and forest degradation in Indonesia since the introduction of REDD + . The next section will focus on several aspects of the complicated and sometimes confusing regulations surrounding forest governance, including the official forest use classification system.

\section{Forest classifications in Indonesia and defining "forests"}

The legal designation of land as official forest (Kawasan Hutan) in Indonesia is not necessarily dependent on whether or not that area has actual forest cover or not, resulting in a dichotomy of forested areas that can be either institutionally recognized or non-institutionally recognized, as well as non-forested areas that are institutionally recognized as official forest. "Official forest" (Kawasan Hutan) refers to land that has been officially designated by the Government of Indonesia as an area under the authority of the Ministry of Forestry (MoF). Within official forest areas, there are further legal classifications of forest based on what that area may be used for-ranging from conservation to production forests for logging and agriculture. Indonesian Forestry Law (article 6 UU-41, 1999) dictates that official forest be categorized according to intended function, with three major categories: protection forest (hutan lindung), conservation forest (hutan konservasi), and production forest (hutan produksi). Production forest is then separated into three further categories: regular production forest (hutan produksi tetap), convertible production forest (hutan produksi konversi), and limited production forest (hutan produksi terbatas). Land that is outside the jurisdiction of the MoF is considered land for other uses (APL), and regardless of whether or not it actually has forest cover, it is not legally considered official forest (See Table 1 for further clarification). This classification system is part of a complex and sometimes confusing system of laws and regulations for forest governance, which contributes to weak institutional capacity and increases opportunities for corruption that lead to mismanagement of resources (Contreras-Hermosilla et al. 2005; Dermawan et al. 2011; Transparency International 2011).

\subsection{Non-institutionally recognized forest}

Indonesia has a significant amount of non-institutionally recognized forests which are very vulnerable to deforestation. Also problematic, and as is discussed further below, some institutionally recognized forests have been converted to non-institutionally recognized forests since the introduction of REDD+. While the designation of an area as institutionally recognized official forest has the potential to offer some degree of protection from deforestation and degradation, even conservation and protection forest is still vulnerable to deforestation (Curran et al. 2004). However, non-institutionally recognized forest, or land with forest cover that is designated as land for other use (APL), is even more susceptible to deforestation and degradation as demonstrated by the high rates of deforestation documented in many of these areas (Margono et al. 2012). Non-institutionally recognized forest areas are more vulnerable to conversion because their designation as such means they are intended for other uses and this makes it easier to obtain land use licenses for those areas. In recent years, an estimated one-third of carbon emissions from Indonesia came from deforestation in areas that were legally designated as land for other uses (APL) with forest cover (non-institutionally recognized forests) (Gregersen et al. 2011). A study of deforestation in Sumatra demonstrated that deforestation in official forest land from 1990 to 2010 ranged from 24 to $29 \%$, but primary forest that was designated as non-institutionally recognized forests (APL) experienced a $96 \%$ loss in forest cover (Margono et al. 2012).

This indicates that much of Indonesia's remaining forests are in a vulnerable position-as of 2013, figures from the MoF indicate that approximately 8.17 million hectares, or approximately $8 \%$, of Indonesia's forest cover is designated as "APL" - or in other words, non-institutionally recognized forest (Indonesia Ministry of Forestry 2014b). Also problematic is the fact that as a result of some of the recent forest-related initiatives, there have been reports from our fieldwork and other cases in the literature of official forest being converted to non-official forest (APL) (Barr et al. 2006; Indrarto et al. 2012), and which has likely contributed to the increase in the deforestation rate since the introduction of REDD+ in Indonesia.

The existence of non-institutionally recognized forest also complicates transparency, accountability, and reporting of figures for forest cover loss. These differences between legal designation and actual land cover are one of the reasons that MoF data on deforestation rates in Indonesia have differed from those reported by other sources; in 2013, the MoF reported approximately 124 million ha of official forest (Indonesia Ministry of Forestry 2014b) but satellite data showed approximately 92.4 million ha of forest cover (Margono et al. 2014). Examples of conflicting data for forest cover and forest cover loss have also been seen among international reporting agencies (Indrarto et al. 2012) but also within the GoI data, among Indonesian governance institutions. For example, in 2012, the Ministry of Environment (MoE) identified 59.8 million ha of forest cover in Papua and the MoF identified 44.2 
Table 1 Legal forest designation, use and area extent as of 2013

\begin{tabular}{|c|c|c|c|c|c|c|}
\hline Forest type & $\begin{array}{l}\text { Indonesian } \\
\text { title and code }\end{array}$ & $\begin{array}{l}\text { Indonesian } \\
\text { forest code }\end{array}$ & Purpose/function & $\begin{array}{l}\text { Possible management } \\
\text { practices }\end{array}$ & $\begin{array}{l}\text { Area } \\
\text { extent } \\
\text { (Million } \\
\text { ha) }\end{array}$ & $\begin{array}{l}\text { Percentage of } \\
\text { forest loss by } \\
\text { forest type for } \\
2011 / 2012 \\
(\%)\end{array}$ \\
\hline Official forest & $\begin{array}{c}\text { Kawasan } \\
\text { Hutan }\end{array}$ & & $\begin{array}{l}\text { Area under the authority of the } \\
\text { Ministry of Forestry }\end{array}$ & $\begin{array}{l}\text { Varies depending on sub- } \\
\text { category (e.g., HL, HP, } \\
\text { HPK) }\end{array}$ & $\sim 131$ & \\
\hline $\begin{array}{l}\text { Sanctuary } \\
\text { Reserve Area } \\
\text { and Nature } \\
\text { Conservation } \\
\text { Area }\end{array}$ & $\begin{array}{l}\text { Kawasan } \\
\text { Suaka Alam } \\
\text { \& Kawasan } \\
\text { Pelestarian } \\
\text { Alam }\end{array}$ & $\begin{array}{l}\text { KSA \& } \\
\text { KPA }\end{array}$ & $\begin{array}{l}\text { Preserving the biodiversity of } \\
\text { flora fauna and their ecosystem }\end{array}$ & Forest preservation & $\sim 22$ & $\sim 5.9$ \\
\hline $\begin{array}{l}\text { Protection } \\
\text { Forest }\end{array}$ & Hutan lindung & HL & $\begin{array}{l}\text { Protecting the water system to } \\
\text { prevent flooding, control } \\
\text { erosion, protect seawater } \\
\text { intrusion and maintain soil } \\
\text { fertility }\end{array}$ & Forest protection & $\sim 30.3$ & $\sim 7.3$ \\
\hline $\begin{array}{l}\text { Permanent } \\
\text { production } \\
\text { forest }\end{array}$ & $\begin{array}{l}\text { Hutan } \\
\text { produksi } \\
\text { tetap }\end{array}$ & HP & Providing forest products & $\begin{array}{l}\text { Selective logging, clear } \\
\text { cutting }\end{array}$ & $\sim 28.8$ & $\sim 25.3$ \\
\hline $\begin{array}{l}\text { Limited } \\
\text { production } \\
\text { forest }\end{array}$ & $\begin{array}{l}\text { Hutan } \\
\text { produksi } \\
\text { terbatas }\end{array}$ & HPT & Low intensity & $\begin{array}{l}\text { Limited logging, very } \\
\text { selective logging, very } \\
\text { limited clear cutting post- } \\
\text { logging silvicultural } \\
\text { treatments }\end{array}$ & $\sim 27.6$ & $\sim 10.7$ \\
\hline $\begin{array}{l}\text { Convertible } \\
\text { production } \\
\text { forest }\end{array}$ & $\begin{array}{l}\text { Hutan } \\
\text { produksi } \\
\text { yang dapat } \\
\text { dikonversi }\end{array}$ & HPK & $\begin{array}{l}\text { Logging, agriculture estate, other } \\
\text { uses }\end{array}$ & Clear cutting & $\sim 15.5$ & $\sim 8$ \\
\hline Non-forest land & $\begin{array}{l}\text { Areal } \\
\text { Penggunaan } \\
\text { Lain }\end{array}$ & APL & & & $\sim 59.4$ & \\
\hline $\begin{array}{l}\text { Non-forest land } \\
\text { with forest } \\
\text { cover }\end{array}$ & $\begin{array}{l}\text { Areal } \\
\text { Penggunaan } \\
\text { Lain } \\
\text { With forest } \\
\text { cover }\end{array}$ & $\begin{array}{l}\text { APL } \\
\text { With forest } \\
\text { cover }\end{array}$ & & & $\sim 8.17$ & $\sim 42.5$ \\
\hline
\end{tabular}

Kawasan Hutan, official forest, is institutionally recognized forest in Indonesia. This is further broken down into sub-categories of Sanctuary Reserve Area \& Nature Conservation Area (KSA/KPA), protection forest (HL), permanent production forest (HP), limited production forest (HPT), and convertible production forest (HPK). Also included here is non-forest land (APL), and non-institutionally recognized forest, which can be found on some non-forest land (APL). Data from (Indonesia Ministry of Forestry 2014a; Margono et al. 2012)

million ha (Samadhi 2013). Other significant reasons for the discrepancies between calculations for forest cover can include the use of different satellite data and also varying definitions of what constitutes a "forest" (Margono et al. 2014).

Definitions of forest can vary greatly, in their 2010 forestry statistics publication the Indonesian MoF defines official forest as, "a specific territory determined and or decided by the government as a permanent forest" (Purnomo et al. 2012, p 76). The FAO defines forest as, "Land spanning more than 0.5 ha with trees higher than 5 meters and a canopy cover of more than $10 \%$, or trees able to reach these thresholds in situ. It does not include land that is predominantly under agricultural or urban land use"(FAO 2006). The FAO defines primary forest as, "Naturally regenerated forest of native species, where there are no clearly visible indications of human activities and the ecological processes are not significantly disturbed" [(UN FAO) Food and Agriculture Organization of the United Nations 2015]. Despite discrepancies that may arise from varying definitions and legal forest designation, an analysis of primary forest defined by Margono et al. as "mature natural forests of 5 ha or more in extent that retain their natural composition and structure, and have not been 
completely cleared and replanted in recent history, including both intact and degraded types" demonstrated that the rate of deforestation and forest degradation in Indonesia from 2000 to 2012 was increasing, with 2012 demonstrating the highest rate of forest cover loss (Margono et al. 2014, p 1).

\subsection{Forest management units}

Further complicating the forest classification system in Indonesia, the 1999 forestry law (Law No. 41/1999) states that all forest areas must be broken down into Forest Management Units (FMUs); however, up until now, this has not been completed. The National Medium-Term Development Plan (RPJMN) and the Strategic Plan of the Ministry of Forestry for 2010-2014 again revitalized the idea of FMUs by stating that FMUs must be designated for all official forest in Indonesia. These FMUs in Indonesia would be considered a separate legal designation from that of the official forest, but would overlap with official forest and sub-categories (such as production forest (HP), convertible production forest (HPK), protection forest (HL)) (Djajono and Siswanty 2011). The intended purpose behind creating these FMUs is to increase the connection between national- and district-level forest governance, increase public access to forest resources, and resolve conflict (Djajono and Siswanty 2011). They are described as, “...decentralized structures for forest management and planning at the site level, adapted to local conditions but linked into the National enforcing forest regulations such as forest fire control and other illegal practices, and negotiating with local communities on issues such as land use rights and forest access" (Government of Indonesia 2012). These FMUs are intended as a means to extend national level control to the forest directly-previously these areas were supposed to be managed by the MoF in Jakarta, but until recently there has been a lack of FMU designation. In cases where FMUs were established, authority over them often remained with district governments, which can be problematic because district interests may conflict with national interests. And furthermore, in many cases the district governments have been unable to enforce current regulations (Yuliani et al. 2010). With the renewed plan for FMUs, the MoF is in effect sending representatives to manage these areas locally, in collaboration with the district agencies, but still under the auspices of MoF oversight. While this has the potential to improve forest governance, it could also allow for further challenges.

Until recently the MoF has legally had control over all institutionally recognized forest as long as it was designated official forest and regardless of whether or not it had been designated as an FMU. But in February 2012, a court ruling, MK45, altered the original definition of official forest, so that it now states that official forest must also be gazetted into FMUs by the MoF to technically be considered official forest and ultimately under the authority of the MoF. From 2009 to 2013, there has been progress in designation of FMUs, but the task is still far from complete (Indonesia Ministry of Forestry 2014b). As of 2012, only 14.2 million hectares, approximately $10.9 \%$ of Indonesia's official forest, has been formally gazetted into FMUs. This means that of the 130.7 million hectares of official forest in Indonesia that was not previously gazetted, a total of 116.5 million hectares, approximately $89.1 \%$, are potentially no longer under the authority of the MoF (Wells et al. 2012).

The MK45 court ruling has the potential to weaken the authority of the MoF and further complicate successful forest management in Indonesia, although it may or may not affect these dynamics in reality. More recent regulations, such as UU/23/2014, which is discussed further in Sect. 3.1, add to these complications by reallocating authority back to the central government. So, while FMU designation has the potential to improve forest governance by decreasing the disconnect between different scales of governance, it could also allow for further challenges-for example, in certain areas the gazetting of an FMU has caused the borders of the National Park to be reduced, increasing the vulnerability of the area no longer included in the national park to conversion (Yuliani et al. 2010). Regardless, such ambiguities and complexities contribute to an already challenging forest governance situation. Even if FMUs are established, many of these areas must also be assessed for tenure; specifically who has possession of current licenses for land use.

\subsection{Forest classification and tenure}

Tenure problems plague forest management and land use in Indonesia. In our fieldwork, multiple instances of overlapping tenure were observed-involving palm oil licenses on community forest, smallholder palm oil encroachment onto REDD+ projects, and artisanal mining in National Parks. Much of Indonesia's official forest has contested tenure-licenses are often issued that contradict the official forest use categories (Indrarto et al. 2012). Problems with tenure play into the aspects of governance discussed here and will be included throughout the discussion as relevant, though tenure issues in Indonesia are comprehensively discussed in many other articles-(Contreras-Hermosilla et al. 2005; Larson et al. 2013; USAID 2010). One of the main tenure challenges relevant to this discussion is discrepancies for who has authority over land among different levels of governance-from the National, to the Province, to the District-and as a result, licenses are sometimes issued that contradict the MoF official forest use 
designation (Barr et al. 2006). Overlapping tenure and licensing can also be found among forest communities, government, and private interests-seen in instances of existing unactivated palm oil and mining concession licenses that overlap with community forests and conservation areas. This kind of overlapping tenure can occur among various interests: between communities and the government; between communities and private companies; between companies and the government; among state institutions; among companies; among communities; and any combination of these as well (Steni and Hadad 2012). These tenure conflicts in Indonesia were observed in our fieldwork, are well documented in the literature, and occur for different reasons such as corruption and exceptions made to forest protection laws but especially because of the overlap overlapping authority among various scales of forest governance (Barr et al. 2010; Eilenberg 2012; Smith et al. 2003). There are many documented cases in which licenses have been issued which contradict the official MoF forest use designation. In some instances, these licenses exist in protection or conservation forest-for example, as of 2011 there were at least 13 mining companies operating in protection forest covering 850,000 ha (Indrarto et al. 2012).

Overlapping tenure is particularly problematic when taking into consideration community forest rights in Indonesia. Such rights in Indonesia are institutionally challenged with less than $1 \%$ of Indonesia's forest governmentally recognized as community forest (Stevens et al. 2014). In many areas of the country, forest communities have been living on and using official forest for generations, but that land is generally considered to be owned by the state and in many cases already licensed out to private interests such as palm oil, timber, or mining companies. For example, approximately $59 \%$ of community forest in West Kalimantan is covered by palm oil concessions not yet activated (Stevens et al. 2014). Examples of this from our fieldwork included maps demonstrating palm oil concessions existing on top of hutan adat (community forest) that had been known to belong to the community for generations.

A court ruling, "Indonesian Constitutional Court decision no. 35/PIU/2012" (known as MK 35) was meant to reform complications with this aspect of forest tenure, stating that hutan adat is no longer state land, or in other words is not under the authority of the MoF and separate from official forest (UNORCID 2013). While MK35 is a step in toward securing community forest tenure, there are still complications to actually establishing indigenous tenure in many cases and it is possible that it will take many years to accomplish such an effort. Yet to date, there are very few areas that have been legally recognized as hutan adat (Stevens et al. 2014), and many stakeholders, including government authorities, have acknowledged that the pathway to do so will likely be time consuming and difficult. In order for such a designation to be made, the government must first recognize local communities as an "indigenous" group, and then their right to the forest must also be established. Considering the already complicated land tenure system, the overlap between national and district authorities regarding forested lands, and the high economic value of forest area, this will be difficult to establish in many cases.

\section{Weak governance}

Although some reforms have been made in recent years, weak forest governance is ubiquitous in Indonesia manifesting as confusing regulations, weak institutional capacity, corruption, overlapping authority, and insufficient sanctions for violations. These issues originate from a history of problematic governance since the period of Dutch colonization, the Suharto Regime, and the subsequent decentralized governance system (Suwarno et al. 2015) as discussed above. Because of these challenges, forest loss in Indonesia is occurring not just in designated production forests, but also in areas that are institutionally recognized and protected (Margono et al. 2014). Between 2000 and 2012, $40 \%$ of all primary forest loss in Indonesia occurred within areas that prohibit clearing (Margono et al. 2014) and a low estimate by the MoF from 2007 quantified approximately 200,000 ha of encroachment per year happening in conservation areas (Murdiyarso et al. 2011). In 2013, MoF statistics report that approximately $13 \%$ of deforestation was in conservation and protection forest (KSA/KPA \& HL) (Indonesia Ministry of Forestry 2014b).

\subsection{Overlapping authority}

Laws are confusing and make identification of violations difficult because the wording of laws and regulations sometimes conflict among each other, and potentially within themselves (Indrarto et al. 2012). Even when there is a clear case of a violation often there are no sanctions in place to punish violators and furthermore authorities often lack the capacity to enforce what sanctions do exist (Faure and Wibisana 2013). Confusing regulations can also exacerbate weak governance when there is ambiguity concerning the authority of national and regional governance, which further leads to conflicts between national goals for forest management and land use and what is happening in reality (Barr et al. 2006). District governments in the Indonesian system wield a fair amount of authority over decisions for land use in their districts, and sometimes their actions may conflict with or override the 
stated intentions of the National government. This is exemplified when the National government may designate a forest area as protected, but later regional authorities can, and do, issue licenses for operating within those areas and then lead to clearing or degradation in protected areas (Contreras-Hermosilla et al. 2005). There have been examples of this happening from both our fieldwork and in the literature (Barr et al. 2006).

While there have been steps taken toward reforming some of these complicated governance dynamics, change happens slowly and is not immediately seen on the ground. One example of this is in 2014, "Law Number 23 about Local Government," UU/23/2014, was passed and was meant to reallocate authority over land use from district governments to provincial and ultimately the central government. If implemented, this law has the potential to have major impacts on forest governance-for one, in most cases permits that conflict with the central government's intentions could no longer be issued by the district. Additionally, it could strengthen the authority of the central government as there will be far fewer provincial governments to control (around 34) while there are over 500 district governments. However, the law has yet to take effect on the ground, and to date district governments have retained authority over forest land use.

Furthermore, corruption in the forestry sector can be connected to the overlap in authority at different scales of governance. Protected areas may be designated at the national level, but enforcement of protected areas falls to local authorities. These authorities may expect to receive incentives in order to stop encroachment and may be used to receiving bribes from other land use interests. Historically, and today, it is not uncommon for companies or individuals wanting to operate within a particular area to give a payment as a bribe or tribute to local authorities (Transparency International 2011; Wadley and Eilenberg 2005), and while this may still be customary it is no longer considered legal. As a result, successful enforcement of forest area boundaries is problematic even when an area is designated as a conservation area (HL/KSA/KPA), REDD + activity, or National Park. In the case of national parks or activities such as REDD+ projects, when there is not likely to be anyone willing or able to make such payment, those areas are left vulnerable to encroachment.

Conservation areas and REDD+ projects face encroachment from both small- and large-scale palm oil, logging, and mining, to which authorities, without sufficient incentives and/or capacity to enforce, turn a blind eye. Examples of this kind of encroachment sometimes occur when agricultural land used by a palm oil company borders a protected area ((WWF) World Wide Fund for Nature 2013; Yuliani et al. 2010) and has also been reported by those running REDD+ activities. Throughout our fieldwork, there were a number of observed and reported incidents of encroachment occurring on protected areas and on REDD+ projects, with virtually no action from local authorities. Encroachment can be small in scale to begin with, perpetuated by corporations, individuals, or small groups, but when not halted by authorities, paid to look the other way; it can spread to cover thousands of hectares, as has happened in a number of National Parks and REDD+ projects already (Hoffman 2014; WWF 2013; Yuliani et al. 2010).

\subsection{Corruption}

It is widely acknowledged that corruption is a problem in Indonesia, particularly in relation to the forestry sector (Dermawan et al. 2011) and which is further compounded by confusing regulations and the legacy of complicated land tenure issues from the Suharto regime (Neef et al. 2007). The pervasiveness of corruption in Indonesia can be seen when looking at the mining sector, one of the main contributors to deforestation-only $40 \%$ of over 10,000 registered mining companies were found to have clean and clear business permits (Cahyat 2014). Revenues associated with forest resources and official forest use-related projects have made it a particularly attractive sector for corruption-it is estimated that between 2007 and 2011, seven billion USD was lost to corruption within the forestry sector and illegal logging activities in Indonesia (Human Rights Watch (HRW) 2013).

There are different types of corruption happening at different levels of forest governance, and all of these manifestations of corruption contribute to deforestation in institutionally protected areas (Smith et al. 2003). And because corruption in Indonesia reaches into the top levels of regional and central government, and across ministries, its eradication is difficult. Transparency and accountability are key to preventing corruption, but have not been integral parts of Indonesian forest governance (Dermawan et al. 2011). While the introduction of REDD+ has brought about opportunities for governance reform and increased accountability, it has done the same for increased corruption. The Government of Indonesia has acknowledged the risk of increased corruption activities related to REDD+, and some steps have been taken toward reform over the past decade. These include the work of a corruption eradication agency, which has brought a number of anti-corruption cases to court in recent years. The Corruption Eradication Commission (Komisi Pemberantasan Korupsi; KPK) was founded in 2002 and also has a special governmental unit dedicated exclusively to natural resource management and governance.

According to an assessment done by the KPK, the MoF was found to be the lowest ranked government ministry in Indonesia on an integrity survey and furthermore responsible for inaccurately mapping forest cover, land use, 
concessions, and unfairly allocating land rights (Human Rights Watch (HRW) 2013). The KPK has had a number of successes, many related to forest governance reform, and for some time, has been considered to be an effective and well-respected agency (Schuette 2012; Stevens et al. 2014). The KPK has also been described as weak for not prosecuting high ranking individuals, and when it has brought charges against such individuals, members of the KPK faced serious pushback in the form of allegations from other agencies (Vernaz 2015). Such controversy could be attributed to problems within the KPK or outside forces at odds with the goals of the KPK (Butt 2011; Dermawan et al. 2011). A revision to the original KPK law was proposed in 2016, which would significantly cut back on the power that the KPK has in investigating corruption. However, while the revision was being discussed, public protests caused the revision to be shelved (Amindoni 2016).

\subsection{Lack of sanctions}

Further characterizing weak governance in Indonesia's forestry sector is the issue of a lack of sanctions for violators. The legal sanctions for violations of forest regulations are nonexistent or too weak to support enforcement (ContrerasHermosilla et al. 2005; Faure and Wibisana 2013; Indrarto et al. 2012). For example, even in some instances when there are clear and identified violations by license holders, licenses have been initially retracted but then later reissued (Indrarto et al. 2012). Adding to the fact that sanctions are scarce, they are also difficult to impose- there is often ambiguity about who may enforce them. This is evidenced by the fact that the Minister of Forestry is responsible for official forest land but does not have the authority to impose sanctions if there are permits issued on the official forest by another sector (Indrarto et al. 2012). Extensive encroachment as described above happens because of corruption, but also weak institutional capacity resulting in part from a lack of sanctions. Another example of the need for stronger sanctions can be seen in the case of the presidential moratorium on new licenses on primary forest. As recently as 2011, there were no sanctions developed in accordance with the moratorium on new licenses in primary forest and within the first 3 months after the moratorium was issued, over 100 incidents of deforestation were recorded in non-concessioned moratorium areas (Austin et al. 2012).

\section{The moratorium}

The presidential moratorium on new concessions for primary forest was announced as a follow-up to Indonesia's public commitment to REDD+ and Letter of Intent with
Norway. Although welcomed by some stakeholders as significant progress in the effort to reduce deforestation rates in Indonesia, many other stakeholder groups were concerned that aspects of the moratorium and its execution could be problematic (ICSCFPGC 2012; Murdiyarso et al. 2011) particularly the fact that it fails to offer new protection to areas not already protected before its creation. While in some ways the moratorium represents the effort and willingness that the GoI has demonstrated in recent years to curb emissions and reform forest governance, it also reflects the complications that characterize the situation in Indonesia. Moreover, the moratorium itself may have been at least partial motivation for the conversion of official forest land to non-institutionally recognized forest.

As discussed in Sect. 2.0, Forest Classification and Defining Forests above, non-institutionally recognized forest is more vulnerable to conversion than institutionally recognized forests. And after the Moratorium was announced, there have been a number of instances of official forest being converted to non-institutionally recognized forest (APL). Examples of this can be found at both the national and sub-national levels. In one instance, 11 days after the moratorium started, a Ministerial Decree ordered 1.2 million hectares of official forest in the REDD+ pilot province of Central Kalimantan to be converted to non-institutionally recognized forest (APL) (Murdiyarso et al. 2011). Another example identified through interviews and fieldwork is in Kapuas Hulu, officially designated as a "conservation district" with two large national parks, Taman Nasional Betung Kerihun and Taman Nasional Danau Santarum. In 2013, approximately $5 \%$ of official forest, institutionally recognized forest estate, in Kapuas Hulu was converted to non-institutionally recognized official forest, or land for other use (APL).

There have been other criticisms regarding the moratorium-one component of this is that when all things are considered the moratorium does not afford protection to as much area as it originally seemed to protect, when taking into account the exceptions to the moratorium and already previously protected forest concessions, only $\sim 26 \%$, or 11.3 million hectares of the 66.4 million hectares of forest cover included the moratorium map is actually given protection by the moratorium (Austin et al. 2012; Murdiyarso et al. 2011). Ultimately at least $29 \%$ of the country's peatlands and $21 \%$ of Indonesia's remaining primary forests are not included in the associated moratorium map, and all of this primary forest is designated as either production, limited production, or convertible forests (Murdiyarso et al., 2011). Looking at the entire area covered by the moratorium, $63.8 \%$ (42.4 million ha) had already been designated as conservation or protection forest area, and another $19 \%$ (12.7 mha) of which is otherwise geographically or legally protected (Austin et al. 2012). 
Other concerns include confusion over terminology used in the presidential instructions, exclusion of some areas of primary forest and peatland, and the practicalities of enforcement. The exclusions refer to the fact that the presidential instructions contained a number of exceptions to the area to be included in the moratorium. One exception is regarding licenses that have "received approval in principle from [the] Minister of Forestry," regardless of whether or not they exist on primary forest or peatland (INPRES 6/2013, p. 2). This has important implications for the scope of the moratorium, as can be seen from differences between the first release of the moratorium map (not excluding these areas) and the second release of the map (which excludes these areas). In the first version of the map, these licenses were not excluded but in the November 2011 updated version, they were removed and resulted in net change of approximately 3.6 million hectares of primary forest and peatland being excluded from the moratorium area, or $7.6 \%$ of the original area from the moratorium (Austin et al. 2012; Wells et al. 2011). And, over 4 million hectares, or $25 \%$ of the moratorium area initially afforded new protection, was later excluded from the moratorium primarily because of preexisting palm oil concessions (Wells and Paoli 2011a, b).

The second and third exceptions have also proven problematic in their ability to protect primary forest cover. The second exception is for, "implementation of national development that is vital, namely: geothermal, oil and gas, electricity, land for rice and sugar cane;" (INPRES 6/2013, p. 2). The mention of electricity in this exception could include coal mining, one of the major drivers of deforestation in Indonesia (Indrarto et al. 2012), responsible for a low estimate of approximately $10 \%$ of deforestation in Indonesia as of 2005 (Contreras-Hermosilla et al. 2005). After the release of the presidential instructions (INPRES 10/2011), a ministerial decree with specific details for implementation was issued to a number of national level ministries, agencies, and sub-national government officials. The ministries and agencies to which this was released notably excluded the Ministry of Agriculture and Ministry of Energy and Mineral Resources, despite their authority over deforestation activities such as palm oil and mining (INPRES 10/2011; INPRES 06/2013; Murdiyarso et al. 2011). The third exception pertains to rights of businesses currently holding licenses to maintain those licenses, regardless of whether they are on high conservation value (HCV) forest at the moment or not. This exception states, "Extension of existing permits for forest exploitation and/ or forestry area utilization as long as the business license remains valid" (INPRES 6/2013, p 2).

The fourth exception has more positive implications as it allows for the granting of Ecosystem Restoration Concessions (ERCs). ERCs are essential to REDD+ implementation in Indonesia, as it allows REDD+ projects to be implemented in production official forest (HP) in Indonesia. This means that forest that is otherwise designated as available for logging, mining, or agricultural concessions can instead potentially be turned into REDD+ projects.

The wording and content of the moratorium itself have also been controversial and in some instances confusing. For example, there is conflict between the text of the moratorium and two earlier editions of the moratorium map (Wells and Paoli 2011a, b). Furthermore, while the moratorium's rather broad definition of peatland can be seen to have an advantage, in that it is broad enough that it includes all areas of peatland greater than $50 \mathrm{~cm}$ in depth that have not already been concessioned (Wells and Paoli $2011 \mathrm{a}, \mathrm{b})$, this is not the case with the way that forest is defined. While the definition of peatland is broad and inclusive, in contrast, the loose terms used to define forest left much of the moratorium open to problematic interpretation.

Controversial is the use of the term "primary forest" as the terminology in the Letter of Intent with Norway was for "natural forest," but that used in the moratorium is "primary natural forest and peatland." As discussed above, definitions of forest vary, but when terms are not explicitly defined in official policy documents it can be problematic for enforcement. In the case of the moratorium, it was the first time that the term "primary natural forest" has been used in Indonesian forest policy. At the time of this publication, there was still no agreed-upon definition in Indonesian policy for "primary natural forest"; those that exist conflict with one another (Murdiyarso et al. 2011). Another problem with the term primary forest is that it could potentially exclude approximately half of Indonesia's forest cover, as it has also been reported by the MoF that primary forest is considered to be forest area that has not been logged (Wells and Paoli 2011a, b). Much of Indonesia's official forest is considered secondary forest, or disturbed forests, areas that are often still rich in biodiversity and carbon stock despite activities such as logging (Murdiyarso et al. 2011; Wells and Paoli 2011a, b). Without clear definitions, documents such as the moratorium remain open to interpretation and can lack the effectiveness to support the intentions behind the document.

Regardless of issues with the moratorium's exceptions, wording, and how forest area was afforded protection by it, the intent behind it was to make it more difficult for companies to obtain licenses for agricultural purposes or mining on area with forest cover. As such, it may have contributed to the increase in deforestation rate by motivating certain parties to convert institutionally recognized official forest into non-institutionally recognized forest 
(APL), as demonstrated by the examples discussed in the results and discussion section of a number of documented cases of institutionally recognized forest being converted into non-institutionally recognized forest, which occurred after the moratorium was announced (Murdiyarso et al. 2011). These converted areas are more vulnerable to conversion as it is easier to obtain licenses in them for nonforest purposes.

\section{Conclusion: prospects for the future}

This article investigates the realities of forest management and some of the reasons behind the increasing rate of deforestation in Indonesia since the introduction of REDD+. Forest policy and governance in Indonesia is complex and resistant to change. Changes in forest policy often happen at the national level and are not always immediately or effectively adopted at the local level as a result of the decentralized governance system in Indonesia. This has lead in the years following REDD+'s introduction, to forest management being conducted in a business as usual mode despite some policy changes. Other reasons behind the increase in the deforestation rate include potential leakage ${ }^{1}$ resulting from institutionally recognized forest being converted to non-institutionally recognized forest (Ekadinata et al. 2010), complex forest tenure (Resosudarmo et al. 2014), and weak and complicated forest governance. While recent efforts, such as the moratorium, have been made by the GoI to strengthen forest governance, the increasing rate of deforestation reflects the difficulty in making significant change. Initial reports from Global Forest Watch indicate that the rate of deforestation in Indonesia has continued to increase into 2013 and 2014, and it is likely that with the recent devastating forest fires of 2015 this number will again be higher than in previous years.

Despite this, the discourse about improving forest governance has increased and along with it new regulations that have the potential to improve forest governance and signal there may be hope for Indonesia's forests and the stakeholders that depend on them. While the majority of stakeholders interviewed indicated some level of fatigue and doubt regarding REDD+, ultimately REDD+ may offer the greatest benefit in its role as a catalyst toward change. REDD+ seems to have initially increased the amount of attention paid to forestry issues in Indonesia (Cronin and Santoso 2010). It is also important to recognize that the Indonesian government has made strides in

\footnotetext{
${ }^{1}$ Leakage is defined as protecting forests in one area causing deforestation in another area (United Nations Framework Convention on Climate Change (UNFCCC) 2010).
}

recent years, and is continuing to demonstrate commitment to this issue (Parlina 2015).

Based on our assessment of forest governance efforts in the wake of the introduction of REDD+, the main areas for governance reform to be targeted for future endeavors should include strengthening governance and increased clarity of regulations and policies. The could be done by increasing sanctions and clarifying who has the authority to issue them as well as continuing to untangle tenure issues through efforts such as the One Map.

Governance reform can be a long and unwieldy process, but by focusing on areas identified as problematic there may be hope for future efforts. For instance, some research indicates that inclusive decision making and increased monitoring and transparency could lead to improvements in decentralized governments (Suwarno et al. 2015). Indonesia has also increased focus on a national monitoring system using remote sensing (Roswintiarti et al. 2013), which has the potential to help improve accountability and is essential for successful REDD+ efforts (de Sassi et al. 2015).

Acknowledgments This research was based on 18 months of fieldwork funded by the Fulbright US Student Program and the University of Maryland. Thanks to Zach Anderson; Belinda Margono; Diana Parker; Dr. Achmand Nurmandi; Dr. Rahmawati Husein; Dr. Eko Purnomo; Universitas Muhammadiah Yogyakarta; and The University of Maryland.

\section{References}

Abood SA, Lee JSH, Burivalova Z, Garcia-Ulloa J, Koh LP (2014) Relative contributions of the logging, fiber, oil palm, and mining industries to forest loss in Indonesia. Conserv Lett. http:// onlinelibrary.wiley.com/doi/10.1111/conl.12103/full

Agung P, Galudra G, Van Noordwijk M, Maryani R (2014) Reform or reversal: the impact of REDD+ readiness on forest governance in Indonesia. Climate Policy, (ahead-of-print), 1-21

Amindoni A (2016) Jokowi and House agree to postpone KPK Law revision-The Jakarta Post. The Jakarta Post. http://www. thejakartapost.com/news/2016/02/22/jokowi-and-house-agreepostpone-kpk-law-revision.html

Anderson BRO (2001) Violence and the State in Suharto's Indonesia. SEAP Publications. http://books.google.com/books?hl=en\&lr= \&id=BF776q2oFKkC\&oi=fnd\&pg=PA7\&dq=suharto+violence \& ots=r4MvzZbMxo\&sig=Pcv255X6CN1xWtMogOx84q8Y61I

Applegate G, Chokkalingam U, Suyanto S (2001) The underlying causes and impacts of fires in Southeast Asia. Final Report. CIFOR, ICRAF, USAID, USFS, Bogor. http://pdf.usaid.gov/ pdf_docs/PNACT614.pdf

Austin K, Sheppard S, Stolle F (2012) Indonesia's moratorium on new forest concessions: key findings and next steps. World Resources Institute Working Paper. WRI, Washington DC

Barber CV, Brown D, Matthews E, Brown TH, Curran L, Plume C (2002) State of the forest: Indonesia. Global Forest Watch and Forest Watch Indonesia. http://agris.fao.org/agris-search/search. do?recordID=GB2013202341

Barr C (2001) Banking on sustainability: structural adjustment and forestry reform in post-Suharto Indonesia. WWF Macroeconomics 
Program Office Washington, DC. http://www.cifor.org/publica tions/pdf_files/books/profits.pdf

Barr CM, Resosudarmo IAP, Dermawan A, McCarthy J, Moeliono M, Setiono B (Eds.) (2006) Decentralization of Forest Administration in Indonesia: implications for forest sustainability, economic development, and community livelihoods. CIFOR. http://books. google.com/books?hl=en\&lr=\&id=-bh1QmnPD_cC\&oi=fnd\& $\mathrm{pg}=\mathrm{PR} 5 \& \mathrm{dq}=$ forest + concessions + sanctions + indonesia\&ots $=$ RnJsm167lp\&sig=FnoVU9WCjYyrMZKqMGvlZATj7Eg

Barr C, Dermawan A, Purnomo H, Komarudin H (2010) Financial governance and Indonesia's Reforestation Fund during the Soeharto and post-Soeharto periods, 1989-2009: a political economic analysis of lessons for REDD+ (vol 52). CIFOR. http://books.google.com/ books?hl=en \&lr=\&id=BaMf9LI-DSQC\&oi=fnd $\& p g=P R 5 \& d q=$ Financial+governance+and+Indonesia\%E2\%80\%99s+Reforestation + Fund + during + the + Soeharto + and + post-Soeharto + periods,$+1989 \% \mathrm{E} 2 \% 80 \% 932009 \&$ ots $=8$ irvhYJQ0P \&sig $=\mathrm{EY}$ xpA47hFSDSRmajR6huT0-aYXs

Brockhaus M, Obidzinski K, Dermawan A, Laumonier Y, Luttrell C (2012) An overview of forest and land allocation policies in Indonesia: Is the current framework sufficient to meet the needs of REDD+? Forest Policy and Economics, 18, 30-37. http://doi. org/10.1016/j.forpol.2011.09.004

Butt S (2011) Anti-corruption reform in Indonesia: an obituary? Bull Indones Econ Stud 47(3):381-394

Cahyat A (2014) Export tax on coal for energy security, safety. Jakarta Post

Carlson KM, Curran LM, Asner GP, Pittman AM, Trigg SN, Adeney JM (2013) Carbon emissions from forest conversion by Kalimantan oil palm plantations. Nat Clim Change 3(3):283-287

Center for Forestry Planning and Statistics, MoF (Ministry of Forestry) (2009) Indonesia Forestry Outlook Study (No. APFSOS II/WP/2009/13). Food and Agriculture Organization of the United Nations Regional Office for Asia and the Pacific

Contreras-Hermosilla A, Fay C, Effendi E, Forest Trends (2005) Strengthening forest management in Indonesia through land tenure reform: issues and framework for action. Forest Trends Washington, DC. http://www.worldagroforestrycentre.org/WCA 2009/regions/southeast_asia/publications?do=view_pub_detail\& pub_no=BK0092-05

Cronin T, Santoso L (2010) REDD+ politics in the media: a case study from Indonesia. CIFOR Working Paper, (49). http://www. cabdirect.org/abstracts/20113382355.html

Curran LM, Trigg SN, McDonald AK, Astiani D, Hardiono YM, Siregar P et al (2004) Lowland forest loss in protected areas of Indonesian Borneo. Science 303(5660):1000-1003

de Sassi C, Joseph S, Bos AB, Duchelle AE, Ravikumar A, Herold M (2015) Towards integrated monitoring of REDD+. Curr Opin Environ Sustain 14:93-100

Dermawan A, Petkova E, Sinaga AC, Muhajir M, Indriatmoko Y (2011) Preventing the risks of corruption in REDD+ in Indonesia. CIFOR. http://books.google.com/books?hl=en\&lr=\&id=K2czHGS_iIcC\& $\mathrm{oi}=$ fnd $\& p g=$ PR $3 \& \mathrm{dq}=$ Preventing + the + risks + of + corruption + in + REDD\%2B+in+Indonesia\&ots=1Sjq_KqXFo\&sig=CG1dah9GI11bOXRT_p2A-2cFsI

Djajono A, Siswanty L (eds) (2011) Forest management unit development-concept, legislation and implementation. Directorate of area management and preparation of forest area utilisation

Eilenberg M (2012) At the edges of states: Dynamics of state formation in the Indonesian borderlands. KITLV Press. http:// www.kitlv.nl/book/show/1319

Ekadinata A, van Noordwijk M, Dewi S, Minang PA (2010) Reducing emissions from deforestation, inside and outside the "forest." ASB PolicyBrief, 16. http://www.worldagroforestrycentre.org/wca2009/ regions/southeast_asia/publications?do=view_pub_detail\&pub_no= PB0010-10

FAO H (2006) Global forest resources assessment 2005. FAO Forestry Paper, 147

Faure M, Wibisana A (2013) Regulating disasters, climate change and environmental harm. Edward Elgar Publishing. http://books. google.com/books?hl=en\&lr=\&id=xQsCAQAAQBAJ\&oi=fnd\& $\mathrm{pg}=\mathrm{PR} 1 \& \mathrm{dq}=$ Regulating + Disasters,+ Climate + Change + and + Environmental+Harm\&ots=01Ixr2YL9v\&sig=Z4HACb6BaUE_ Qp110icsXmu49KU

Fitzherbert EB, Struebig MJ, Morel A, Danielsen F, Brühl CA, Donald PF, Phalan B (2008) How will oil palm expansion affect biodiversity? Trends Ecol Evol 23(10):538-545

Food and Agriculture Organization of the United Nations (2012) Forest management and climate change: a literature review (No. Paper 10). Rome: Food and Agriculture Organization of the United Nations

Food and Agriculture Organization of the United Nations (UN FAO) (2015) Forest resources assessment working paper: terms and definitions (Forest resources assessment working paper no. 180), Rome

Government of Indonesia (2012) Forest investment program Indonesia forest investment plan. http://forestclimatecenter.org/files/ 2012-09-26\%20Forest\%20Investment\%20Program\%20-\%20Indonesia\%20Forest\%20Investment\%20Plan.pdf

Government of Norway, Government of Indonesia (2010) Fact sheet Norway-Indonesia partnership REDD+. http://www.norway.or. id/PageFiles/404362/FactSheetIndonesiaGHGEmissionMay2520 10.pdf

Gregersen H, El Lakany H, Bailey L, White A (2011) The greener side of REDD+: lessons for REDD+ from countries where forest area is increasing. Rights and Resources Initiative, Washington DC

Hansen MC, Stehman SV, Potapov PV, Arunarwati B, Stolle F, Pittman K (2009) Quantifying changes in the rates of forest clearing in Indonesia from 1990 to 2005 using remotely sensed data sets. Environ Res Lett 4:34001

Hansen MC, Potapov PV, Moore R, Hancher M, Turubanova SA, Tyukavina A, Loveland TR (2013) High-resolution global maps of 21st-century forest cover change. Science 342(6160):850-853

Harris N, Minnemeyer S, Sizer N, Mann S, Payne O (2015a) With latest fires crisis, Indonesia surpasses Russia as world's fourthlargest emitter I World Resources Institute. World Resources Institute. http://www.wri.org/blog/2015/10/latest-fires-crisis-indo nesia-surpasses-russia-world\%E2\%80\%99s-fourth-largest-emitter

Harris N, Minnemeyer S, Stolle F, Payne O (2015) Indonesia's fire outbreaks producing more daily emissions than entire US economy I World Resources Institute. World Resources Institute. http://www.wri.org/blog/2015/10/indonesia\%E2\%80\%99s-fireoutbreaks-producing-more-daily-emissions-entire-us-economy

Hoffman D (2014) Harapan rainforest. Retrieved 24 Jan 2014, from http://www.rspb.org.uk/supporting/campaigns/rainforests/indone sia.aspx

Human Rights Watch (HRW) (2013) The dark side of green growth the human rights impacts of weak governance in Indonesia's forestry sector. Human Rights Watch

Indonesia Ministry of Forestry (2014a) Forest Area Statistics 2013. Jakarta: Indonesia Ministry of Forestry. http://www.dephut.go. id/uploads/files/2fba7c7da8536e31671e3bb84f141195.pdf

Indonesia Ministry of Forestry (2014b) Ministry of Forestry Statistics 2013. Jakarta: Indonesia Ministry of Forestry. http://www. dephut.go.id/uploads/files/2fba7c7 da8536e31671e3bb84f141195.pdf

Indrarto GB, Murharjanti P, Khatarina J, Pulungan I, Ivalerina F, Justitia $\mathrm{R}$ et al. (2012) The context of REDD+ in Indonesia: drivers, agents 
and institutions. http://forestclimatecenter.org/files/2012-08-09\% 20The $\% 20$ Context $\% 20$ of $\% 20$ REDD+\%20in\%20Indonesia.pdf

Ipcc A (2014) Climate change 2014: synthesis report. IPCC Geneva, Switzerland

Kissinger G, Herold M, De Sy V (2012) Drivers of deforestation and forest degradation: a synthesis report for REDD+ policymakers. Vancouver: Lexeme Consulting. http://www.era-mx.org/biblio/ Drivers $\% 20$ of $\% 20$ deforestation $\% 20$ and $\% 20$ forest $\% 20$ degradation. pdf

Larson AM, Brockhaus M, Sunderlin WD, Duchelle A, Babon A, Dokken T et al. (2013). Land tenure and REDD+: the good, the bad and the ugly. Glob Environ Change. http://doi.org/10.1016/j. gloenvcha.2013.02.014

Margono BA, Turubanova S, Zhuravleva I, Potapov P, Tyukavina A, Baccini A et al (2012) Mapping and monitoring deforestation and forest degradation in Sumatra (Indonesia) using Landsat time series data sets from 1990 to 2010. Environ Res Lett 7(3):34010

Margono BA, Potapov PV, Turubanova S, Stolle F, Hansen MC (2014) Primary forest cover loss in Indonesia over 2000-2012. Nat Clim Change. http://www.nature.com/nclimate/journal/vaop/ncurrent/ full/nclimate2277.html?utm_source=Daily+Carbon+Briefing \& utm_campaign=1f7e4f67b5-DAILY_BRIEFING\&utm_medium= email\&utm_term=0_876aab4fd7-1f7e4f67b5-303421281

McCarthy J (2000) The changing regime: forest property and reformasi in Indonesia. Dev Change 31(1):91-129

McCarthy J (2004) Changing to gray: decentralization and the emergence of volatile socio-legal configurations in central Kalimantan, Indonesia. World Dev 32(7):1199-1223

McFarland W, Whitley S, Kissinger G (2015) Subsidies to key commodities driving forest loss: Implications for private climate finance. Overseas Development Institute

Murdiyarso D, Dewi S, Lawrence D, Seymour F (2011) Indonesia's forest moratorium: a stepping stone to better forest governance? CIFOR. http://www.google.com/books?hl=id\&lr=\&id=tK4i9uUZ z10C\&oi=fnd\&pg=PP5\&dq=daemeter + moratorium\&ots=zmxP6 Fq_tR\&sig=1SpYHsMAFRpw1YMuSs-dWt2854

Natahadibrata N (2013) Government recognizes customary forests. The Jakarta Post. http://www.thejakartapost.com/news/2013/05/ 18/government-recognizes-customary-forests.html

Neef A, Sirisupluxana P, Wirth T, Sangkapitux C, Heidhues F, Thu DC, Ganjanapan A (2007) 6.2 resource tenure and sustainable land management - case studies from northern Vietnam and northern Thailand. In: Sustainable land use in mountainous regions of Southeast Asia: meeting the challenges of ecological, socio-economic and cultural diversity, p 317

Parlina I (2015) RI-Norway agree to continue REDD+. The Jakarta Post. http://www.thejakartapost.com/news/2015/04/15/ri-norwayagree-continue-redd.html

Purnomo H, Suyamto D, Abdullah L, Irawati RH (2012) REDD+ actor analysis and political mapping: an Indonesian case study. Int For Rev 14(1):74-89

Resosudarmo IAP, Atmadja S, Ekaputri AD, Intarini DY, Indriatmoko Y, Astri P (2014) Does tenure security lead to REDD+ project effectiveness? Reflections from five emerging sites in Indonesia. World Dev 55:68-83

Roswintiarti O, Tjahyaningsih A, Furby S, Wallace JM et al. (2013) Indonesia's national carbon accounting remote sensing program-A national system for monitoring forest changes. In Geoscience and Remote Sensing Symposium (IGARSS), 2013 IEEE International (pp. 3930-3933). IEEE. http://ieeexplore. ieee.org/xpls/abs_all.jsp?arnumber $=6723692$

Samadhi N (2013) Indonesia ONE MAP: Assuring Better Delivery of National Development Goals Monetizing Geospatial Value and Practices For National Developmental GoalsSamadhi. Presented at the Geospatial World Forum 2013, Rotterdam
Santosa MA, Khatarina J, Suwana AS (2013) The progress on governing REDD+ in Indonesia. International Journal of Rural Law and Policy. http://epress.lib.uts.edu.au/journals/index.php/ ijrlp/article/view/3356

Schuette SA (2012) Against the odds: anti-corruption reform in Indonesia. Public Adm Dev 32(1):38-48

Simamora AP (2011) SBY vows to protect palm oil interests. The Jakarta Post. http://www.thejakartapost.com/news/2011/03/26/ sby-vows-protect-palm-oil-interests.html

Smith J, Obidzinski K, Subarudi S, Suramenggala I (2003) Illegal logging, collusive corruption and fragmented governments in Kalimantan, Indonesia. Int For Rev 5(3):293-302

Steni B, Hadad N (2012) REDD+ safeguards in Indonesia. Bank Information Center, World Resources Institute, HUMA

Stevens C, Winterbottom R, Springer J, Reytar K (2014) Securing rights, combating climate change: how strengthening community forest rights mitigates climate change. World Resources Institute, Washington, DC

Susilo Bambank Yudhoyono H (2013) Translation of presidential of the republic of Indonesia instruction number 6 year 2013 on suspension new licenses and improving forest governance of primary forest and peatland. Daemeter Consulting

Suwarno A, Hein L, Sumarga E et al (2015) Governance, Decentralisation and Deforestation: the case of Central Kalimantan Province, Indonesia. Q J Int Agric 54(1):77-100

Tacconi L (2003) Forest fire in Indonesia: cause, cost, policy implication. CIFOR Occasional Paper, (38)

The Indonesian Civil Society Coalitions for Forest Protection and Global Climate (ICSCFPGC) (2012) Towards a performancebased moratorium: one year reflection on moratorium policy and indonesian civil society recommendations for strengthening and extending the deforestation moratorium, Jakarta

Transparency International (2011) Forest Governance Integrity Report Indonesia. Indonesia: Transperancy International. http:// www.ti.or.id/media/documents/2011/11/23/f/a/faaa1-report_indo nesia_final_rev.pdf

UN REDD Programme (2015) UN-REDD Programme-About REDD+. Retrieved 5 Jan 2015, from http://www.un-redd.org/ aboutredd/tabid/102614/default.aspx

Unit Kerja Presiden Bidang Pengawasan Dan Pengendalian Pembangunan (UKP4) (2012) One Map Indonesia. Presented at the One Map Midway Workshop 2012, Jakarta

United Nations Framework Convention on Climate Change (UNFCCC) (2010) National greenhouse gas inventory data for the period 1990-2008. Retrieved 16 Feb 2011, from http:// unfccc.int/documentation/documents/advanced_search/items/35 94.php?rec $=j \&$ priref $=600006019 \#$ beg

United Nations Office for REDD+ Coordination in Indonesia (2013) Presented at the national workshop on the forestry law: constitutional court ruling No. 35/PUU-X/2012, Jakarta

USAID (2010) USAID Country Profile: Property Rights and Resource Governance Indonesia

Van der Werf GR, Morton DC, DeFries RS, Olivier JG, Kasibhatla PS, Jackson RB et al (2009) $\mathrm{CO}_{2}$ emissions from forest loss. Nat Geosci 2(11):737-738

Vernaz F (2015) Weakening of the KPK: Corruptors' $€^{\mathrm{TM}}$ fight-back manual-The Jakarta Post. The Jakarta Post. http://www. thejakartapost.com/news/2015/01/27/weakening-kpk-corruptorsfight-back-manual.html

Wadley RL, Eilenberg M (2005) Autonomy, identity, and "illegal" logging in the borderland of West Kalimantan, Indonesia. Asia Pac J Anthropol 6(1):19-34

Wells P, Paoli G (2011) An analysis of Presidential Instruction No. 10, 2011: moratorium on granting of new licences and improvement of natural primary forest and peatland governance. Daemeter Consulting 
Wells P, Paoli G (2011) Preliminary Observations on the Indonesian Ministry of Forestry Decree SK.323/Menhut-II/2011 and Indicative Maps Concerning the Suspension of New Licenses for Forest and Peatland Utilisation. Daemeter Consulting

Wells P, Franklin N, Paoli G (2011) Preliminary observations on the Indonesian ministry of forestry decree SK.7416/Menhut-VII/ IPSDH/2011: The first revision of the indicative maps concerning the suspension of new licenses for forest and peatland utilisation (Daemeter Briefs on the Indonesian Moratorium No. 3)

Wells P, Franklin N, Gunarso P, Paoli G, Mafira T, Kusumo DR, Clanchy B (2012) Indonesian constitutional court ruling number 45/PUU-IX/2011 in relation to Forest Lands: Implications for Forests, Development and REDD+. Daemeter Consulting
World Resources Institute Global Forest Watch (WRI GFW) (2016) Indonesia I Global Forest Watch. http://www.globalforestwatch. org/country/IDN

World Wide Fund for Nature (WWF) (2013) Palming Off a National Park: Tracking Illegal Oil Palm Fruit in Riau, Sumatra. http:// awsassets.wwf.or.id/downloads/wwf_indonesia_palming_off_a_ national_park_final.pdf

Yuliani L, Indriatmoko Y, Salim A, Farid IZ, Muhajir M, Prasetyo LB, Heri V (2010) Biofuel policies and their impact on local people and biodiversity: a case study from Danau Sentarum. https://mahider.ilri.org/handle/10568/20773 